\title{
GENDER AND MIGRATION IN GREECE: THE POSITION AND STATUS OF ALBANIAN WOMEN MIGRANTS IN PATRAS
}

\author{
Dimitra Charalampopoulou ${ }^{1}$
}

\begin{abstract}
Greece has experienced major changes in its migration patterns. After a century or so of emigration, it has now become a country of immigration. Much academic research has concentrated on the impact this change has on Greek society. However, there is a tendency to ignore the role that gender plays in the migration process. This article addresses the issue of Albanian immigration to Greece, focusing on the aspect of gender. It presents the living and working conditions of Albanian women who migrate to Greece, especially to one of its cities, Patras. It examines the new migration process through the eyes of women migrants. It is centred on their narration about their journey to Greece, their decision to migrate, the problems that they face, their experiences and plans for the future: in short, their life stories. Finally, the article draws attention to the need for further research on issues concerning migrant women in Greece.
\end{abstract}

Key words: Greece, Albanian women, Patras, gender, migration.

Resumo - Género e migrações na Grécia: estatuto das mulheres em Patras. A inserção da Grécia nos padrões migratórios mundiais tem vindo a passar por diversas transformações significativas. Após cerca de um século de história de emigração, este país tornou-se recentemente um destino para os fluxos migratórios. Numerosos estudos académicos têm incidido sobre o impacte destas transformações sobre a sociedade grega. No entanto, existe uma tendência para se ignorar o papel do género no processo migratório. Este artigo incide precisamente sobre esta questão, através do estudo das imigrantes albanesas na Grécia. São apresentadas as condições de vida e de trabalho das imigrantes albanesas neste país e, em particular, numa das suas cidades: Patras. Procede-se a uma análise dos novos processos migratórios através do olhar das mulheres migrantes. $\mathrm{O}$ artigo centra-se nos seus relatos acerca da sua viagem para a Grécia, da sua decisão de migrar, dos problemas que enfrentam e das suas experiências e planos para o futuro: em suma, nas suas histórias de vida. Por fim, o artigo chama a atenção para a necessidade de prosseguir e aprofundar a investigação acerca de temas relacionados com a situação das mulheres imigrantes na Grécia.

Palavras-chave: Grécia, mulheres albanesas, Patras, género, migrações.

1 Sussex European Institute, Univ. of Sussex. E-mail: d.charalampopoulou@sussex.ac.uk 


\section{INTRODUCTION: GREECE AND THE NEW MIGRATION CONTEXT}

Why is migration important nowadays and why should we give our attention to the new migration patterns? What makes recent migration patterns distinctive? Castles and Miller would answer that what is distinctive about the 'new migrants' in recent years is 'their global scope, their centrality to domestic and international politics and their enormous economic and social consequences' (CASTLES and Miller, 1998: 1). They go on to identify five general tendencies: first, the globalisation of migration, the tendency for increasingly more countries to be affected by migratory movements at the same time and the increasing diversity of the areas of origin; second, the acceleration of migration, the fact that migrations are growing in volume in all major regions at the present time; third, the differentiation of migration which means that most countries do not simply have one type of immigration, such as labour migration, refugee or permanent settlement, but a whole range of types at once; fourth, the feminisation of migration, which means that women play an increasing role in all regions and all types of migration; and fifth, the growing politicisation of migration.

Southern Europe, and Greece in particular, has been greatly affected by these new global migration trends. Together with Italy, Spain and Portugal, Greece turned itself very quickly from a country of mass emigration, which it had been up to the mid-1970s, to one of mass immigration in the $1980 \mathrm{~s}$ and 1990s. Already in 1987 Gildas Simon wrote that the 'new immigration' in Southern Europe is characterised by its clandestine nature, the great variety of immigrant nationalities, the fundamental role of the 'new underground economy' and the lack of national policies to cope with the uncoordinated influx (SIMON 1987: 287). To this list can be added one of Castles' key indicators of the new immigration scenario: its gendered nature. This feminisation of migration provides the main focus of the paper, which will analyse the experiences of Albanian migrant women in one Greek city.

The paper is organised in the following way. First, three brief background sections are introduced: on women in migration, the 'migration turnaround' in Greece, and policy and other reactions of Greek society. Then I will outline the research methodology of my fieldwork study of Albanian women in Patras. The main body of the paper will describe the women's multiple experiences as migrants: their arrival and settlement, their work, their social networks, and plans for the future.

\section{WOMEN IN MIGRATION LITERATURE}

Although movements of people across borders have shaped states and societies for a long time now, women migrants are virtually absent from the early literature on migration. Most studies on migration have used exclusively 
male samples and so migration appears as a male affair only, even in cases where the sex ratio in the migratory movements was in favour of females (see PhizaCKLEA, 1983). Through the 'guest-worker' period the idea of man as the prototype migrant, as the decision-maker, was developed. As MoroKVASIC (1983) explains, women were mentioned only as an accessory of a process they were not really taking part in. While 'the migrant' is a broad category covering a wider range of subtypes and subcategories and so it could be either male or female, it was more common to refer to a migrant as male.

Another feature of the early migration literature on women is that, whenever women were not neglected, they were mentioned within the framework of the family, in relation to children. According to LAZARIDIS (2000), literature relied on stereotypes of migrant women as wives or mothers, isolated, maybe illiterate, secluded from the outside world and the bearers of many children. In the common expression 'migrants and their families', 'families' are understood to be composed of dependent members - women and children - while the 'migrant' was considered to be a male breadwinner.

MoROKVASIC (1983: 18-19) argues that 'this deliberate exclusion of women is usually justified by the lack of research funds and by women's supposedly minor economic role' and she goes on to explain that the emergence of a literature on migrant women owes much to two circumstances: 'one is a wider feminist questioning about women's role in society, the other is a recognition of migrant women as economically important'. In another line of argumentation from the early 1980s, PHIZACKLEA and Miles (1980) referred to women and capitalism and their dual role in production. Phizacklea (1983) drew attention to structural changes in the world economy and the creation of 'hidden armies' of female migrant labour in her landmark One Way Ticket. Around the same time, MoROKVASIC (1984) focused also on labour migration and argued that access to employment does not necessarily emancipate migrant women. SIMON and BRETTELL (1986) emphasised cultural elements influencing migration, family life and reproduction and recognised a greater variety of migrant categories, including refugees. Meanwhile the work of WING (Women, Immigration and Nationality Group) in their Worlds Apart: Women under Immigration and Nationality Law (WING 1985) brought about public interest, notably in the difficulties migrant women faced due to inhuman immigrant policies and legislation which had never given women independent status and instead treated them as appendages of men.

During the 1990s, the diversity in women's experiences quickly became apparent and a significant number of studies of female migration developed. Anthias's work (1992) focuses on the Cypriot migration to Britain and provides an account of the economic and social position of Greek Cypriot women in British society. In Homeworking Women (1995), Phizacklea and Wolkowitz question the assumption that homeworking is attractive and technologically advanced, revealing that the traditional portrayal of the manufacturing homeworker sweating over a sewing machine is not a thing of the past. 
Recently, studies on female migration have centred on the European dimension and the impact of fortress Europe on migrant women (MOROKVASIC, 1991; Kofman and SALES, 1992; Essed, 1995). Other works are focused on the geopolitical and economic changes that have created and accelerated large flows of migrant and refugee women in Southern Europe. CHELL (1997) studies the immigration of Somalian and Filipina women in Rome. CAMPanI (1999; 2000) provides challenging overviews of immigrant women in Southern Europe, focusing on domestic workers and prostitutes in Italy. Her work avoids the categorisation 'the maid' and 'the prostitute' and demonstrates the power of women, even working as prostitutes, to take some control over their lives. This must be balanced against the tragic evidence she also presents concerning the trafficking and brutal exploitation of migrant women, especially those from Nigeria and Albania who are often trapped in a vicious cycle of prostitution, indebtedness, deceit and violence from which escape is almost impossible. The edited book of ANTHIAS and LAZARIDIs (2000) is the first to be entirely devoted to the analysis of gender and migration in Southern Europe, and therefore fills an important gap in the available literature. Important is also the recent work of KofmAN et al. (2000) on gender and international migration in Europe.

The above studies show a turn of attitude and an intense interest to study women's migration - and especially in Southern Europe - more and in depth. However, the same does not occur in my specific area of study, Greece, where only a few interesting publications on women migrants' issues have been produced. Psimmenos' work (1995) examines young Albanian women in the sex industry of Athens. Using the notion of 'periphractic' space (from the Greek 'fencing in') to denote the spatial dimensions of marginalisation and social exclusion, Psimmenos posits the production of a slave labour force, existing on the margins and 'fenced in' by society. LAZARIDIS (2000), focusing on the experiences of Filipina and Albanian women in Greece - and especially in Corfu shows how racism interacts with sexist relations within Greek society and how the interplay between them produces different outcomes. IOSIFIDES (1997) makes a comparative analysis of the labour market position, functions and conditions of three immigrant groups, Albanians, Egyptians and Filipinos. His sample is mainly male-composed but there are some interesting findings about Filipina women. Other interesting findings about migrant women we can find in the works of LAZARIDIS (1999) and ROMANISZYN (1999) who examine the stigmatisation and social exclusion of Albanian and Polish migrants in Greek society.

However, these studies are insufficient to cover the range and depth of issues that concern migrant women in Greece, being overly concentrated on migrant sex workers, stigmatisation and, to use Lazaridis's phrase, 'multiple layers of oppression'. More important is the fact that the situation of migrants in Greece has changed very fast since the early 1990s, especially after the two legalisation procedures, one in 1998 and the second in 2001. 


\section{THE MIGRATION TURNAROUND IN GREECE}

For the most of the twentieth century Greece was a country of mass emigration towards various destinations. Greek emigration can be broadly divided into two sub-periods: before and after the Second World War. Between 1900 and 1924 an estimated 420,000 left Greece for overseas destinations, mainly the United States (Iosifides, 1997). After the Second World War, due to severe social and economic problems, emigration accelerated and the exodus was covertly supported by successive Greek governments as an additional aspect of their economic and development policies (IOSIFIDES, 1997). According to Fakiolas (2000), nearly a million Greeks emigrated during the period 1945-73, with West Germany the main destination after 1961. The broad causes of postwar Greek emigration can be related to various factors ranging from political reasons, especially after the 1946-9 civil war, to high levels of open unemployment, poverty and hardship both in the countryside and in several towns and cities (FAKIOLAS and King, 1996; Pteroudis, 1996).

However, after 1970, emigration started to decline and return migration began to take place on a large scale. During 1974-85, almost half of the Greeks in Europe repatriated (FAKIOLAS, 2000). The most important contributing factors behind this change were the relative deterioration of economic and labour market conditions in various destination countries, especially after the oil crisis of 1973, the difficulties of proper assimilation in host countries (especially in Germany) and the restoration of parliamentary democracy in Greece in 1974, after which there followed a period of economic development and low unemployment (Iosifides, 1997; Mousourou, 1991; Pteroudis, 1996). Towards the end of this period, both emigration from and return migration to Greece reached insignificant levels and net migration moved close to zero (FAKIOLAS, 2000). In the 1980s, foreign immigration replaced return migration as the key element in the positive migratory balance of the country (PETRINIOTI, 1993).

There are many reasons for the transformation of Greece into an immigration country: the persistence of a large informal economy in Greece; the fragmentation of the economy into a myriad of small, mainly family-run enterprises; the seasonality and labour intensity of many sectors of the economy such as agriculture, fishing, tourism, construction and shipping; and the rejection of low-paid, low-status jobs by natives due to higher educational levels, higher socio-economic aspirations and the delayed labour market entry of the young. All the above result in the demand for low-paid unskilled migrant labour, and constitute a set of pull factors. The strongest push factor is the political and economic change in the countries of Eastern Europe after 1989-90 and the closeness of Greece to these countries. The imposition of stricter immigration controls by the traditional host countries of North-West Europe in combination with the relatively lax Greek immigration policy is another factor.

The immigrant population in Greece comprises three main categories. First, there are ethnic-Greek immigrants from several republics of the former USSR, 
Albania and to a lesser extent from other Eastern European countries. According to the National Foundation for the Reception and Settlement of Greek Return Migrants, between 1987 and 1993, 47,436 ethnic-Greeks arrived and settled in the country, mainly from the former Soviet Union (PETRINIOTI, 1993: 18). The second category is legally employed foreigners. In 1992 there were 33,892 legally employed foreigners in the country, two-thirds of whom were from other EU or European countries (KaTSORIDAS, 1994). Other legally employed come from East European, African and Asian countries. The last category includes all the migrants entering the country illegally. Before the legalisation procedures only estimations could be made about their approximate number. Various estimates put the numbers of Albanians at between 150,000 and 200,000, Poles at around 100,000, Egyptians at about 55,000 and Filipinos at between 30,000 and 40,000 (Iosifides, 1997; Pteroudis, 1996). There were also smaller but nevertheless significant immigrant communities from Iraq, Pakistan, Bulgaria, and the former Yugoslavia.

The 2001 Census showed that there are 761,813 foreigners, of whom 415,669 are men and 346,144 are women. The largest ethnic group is that of Albanians with a total of 438,036 . Albanian women also comprise the largest group of women migrants in Greece, with 180,856. Other significant groups of women migrants are Bulgarians $(21,179)$, Georgians $(13,024)$, Russians $(10,976)$, Ukrainians $(10,264)$, Romanians $(9,542)$, Poles $(6,959)$ and Filipinas $(4,928)$. According to FaKIOLAS (2000), immigrants comprise between 9 and 11 per cent of the registered Greek labour force of 4.4 million and over 25 per cent of wage and salary earners. It seems that Greece has, in proportion to its population, more immigrants than any other Southern European country.

\section{POLICY RESPONSES AND REACTIONS OF GREEK SOCIETY}

The response of the Greek State to the new immigration pressures has been complex and contradictory. The official line has been that 'Greece is not a country of immigration' (GLYTSOS, 1995: 168).

In October 1991 the Greek Parliament passed a new immigration law. Law 1975/1991 replaced Law 4310/1929 which had been in effect for more than 60 years. More specifically, the new Law did not apply to Greek nationals, stateless persons and those under the jurisdiction of EU legislation. The police became more empowered to check those entering or leaving the country for appropriate travel documents; strict entry requirements were laid down; illegal migrants could be expelled without trial and a special police force was set up. Residence permits were granted for employment with pre-entry authorisation; they were employer-specific and valid for one year, renewable for up to five years. After five years, a two-year permit could be given by joint decision of the Ministries of Public Order and of Labour. After 15 years' residence (excluding years of study) and ten years' social insurance contributions, a permit of indefinite duration 
could be granted. Migrants holding a two-year residence permit could request similar residence permits for their immediate family (defined as spouse, parents and unmarried children aged under 18).

The passage of the bill was difficult and it was condemned for xenophobia and a policing philosophy, as well as taking no account of immigrants already present in the country. So, in 1996, Law 2434/1996 came into practice in order to define in a more complete way the procedures and requirements for legal migrants' entry, work and residence in the country and start changes in the field of education for the migrants' children. Since then many sets of policies have been passed by the Greek Parliament in order to better define the requirements for entry into the country and to coordinate and share the responsibilities of migration policy among the Ministries of Public Order, Interior Affairs and Public Administration.

More recently, there have been two legalisations in 1998 and 2001. In May 2001, the Greek Parliament passed Law 2910/2001 in response to critics that the Greek State constantly ignores the fact that Greece is a country of immigration - and mostly of 'illegal' migrants. So, once more the Law concentrates on illegal migrants and this time on their legalisation, taking no account of other important matters that trouble the lives of immigrants already present into the country. It declares its objective to be the accession of economic migrants into the Greek society. However, a careful study of the Law shows that it is created in order to defend the interests of Greek employers and the Greek State, and treats migrants virtually as slaves. For example, entry and work permits will be allowed according to the needs of the Greek labour market; employers can notify the local administrations of the number of workers they need each time (especially for seasonal labour). The illegal migrants can gain legal stay after a whole bureaucratic procedure which would be forbidding enough for a Greek national, but which is especially difficult for a foreigner. Others who stay illegal will be prosecuted and expelled. Also, doctors and health administrators are not allowed to treat illegal migrants or else they will be prosecuted. Furthermore, hotel and health managers have to notify the police of the arrival and departure of every migrant in their buildings.

The sudden change of Greece into an immigration country in combination with the lack of an effective migration policy have had negative impacts on Greek society. The uncontrolled influxes of large numbers of economic migrants, political refugees and asylum-seekers in combination with an increase in recorded crime (KARYDIS, 1996) have led to the criminalisation of migration by the Greek society and especially by the media. Media interest has centered principally on one group of migrants, the Albanians, as these constitute the largest group of migrants in Greece.

As LAZARIDIS (1999) explains, the tactic employed by the mass media of connecting Albanian migration with criminality and its characterisation as 'imported' criminality provokes a feeling of growing insecurity in Greek society. This has led to xenophobic and racist reactions against the dangerous 'others', 
or 'Albanophobia'. Dichotomous categories like criminal/non-criminal, dangerous/ not dangerous, and good/bad are often used by the media, capped by headlines such as 'Albanians... a crime per day' (Apogevmatini, 05/01/92). Media are also responsible for showing immigrants as responsible for the high levels of unemployment and the low level of quality of life of a large group of the Greek population: ' $37 \%$ of the Greek population is ruined economically... from the impact of illegal immigration on the Greek economy' (Eleutherotypia, 05/03/01).

Women migrants have also provoked the interest of media: 'Probe into huge prostitution racket' ( $H$. Kathimerini, 06/12/00). Articles and headlines present migrant women as prostitutes and as victims of human traffickers. But also, with sympathy, they see the efforts of migrant women to build a support organisation in Greece: '17 speakers and 400 attendees at the first Foreign Women in Greece Network meeting' (H. Kathimerini, 21/06/01).

Lately, one can also ascertain that there is a slight difference in the way media see the presence of migrants in Greece as they condemn the presence of xenophobic emotions among the Greek population. Some newspapers criticise the official policies for migrants: for instance 'Fear, ignorance and lack of proof hound legalisation' (Athens News, 20/07/01). However, it might be too late to dissolve the xenophobic feelings within Greek society that the media created during the first years of migrants' entry.

\section{RESEARCH QUESTIONS AND METHODOLOGY}

The research component of this paper is based on interviews, statistical data and secondary data. By far the most important element of the fieldwork research in Patras was a set of in-depth interviews with women migrants residing and working in the area. While quantitative data can be useful for assessing the numerical significance of women in migration fluxes the nature of the migrant experience and the variations between different women migrants are better understood through the use of qualitative data. As Kofman et al. (2000) argue: 'qualitative data often provide a holistic view of women's experiences. These sources have been better able to reveal the different spatio-temporal dimensions of female migration, the multiplicity of causes for their moves and the often overlapping strategies used by women migrants. It provides a flavour of the heterogeneity of migration, the range of ages at which people migrate, the varying skills they bring with them, the different reasons for moving, and for staying or moving again, the social relations that facilitate migration and the regimes that influence migrant trajectories'. They also highlight the significance of gender as a key variable in the experience of migration. Furthermore, the purpose of the study, which is the identification of underlying processes, practices and problems related to migration and settlement, increased the desirability of employing more qualitative approaches. 
Key questions behind the research are:

- How do Albanian migrant women take the decision to migrate to Greece? Which conditions 'push' these women to migrate? What are the reasons for leaving their country? Are they protagonists in the migration process?

- What strategies do they use in order to settle and get acquainted with the new environment? Do they depend on their husbands for support networks or on themselves?

- Does their role change with the migration process, for instance from being housewives to being workers and earners, or from being isolated to being interactive, or vice versa? Do they experience a decline or an improvement in their social position through migration?

- Does the migration process change their way of life, their traditions, their lifestyle and in what way (for example, in the way of upbringing their children, their consumption habits, etc.)?

- Do women migrants constitute a reserve army of labour? Do migrant women occupy a subordinate position within sectors of 'women's work'?

- What are their working and living conditions? What are the main problems that they face?

- How do they cope with the stigmatisation and the image that Greek society attributes them?

- How do they see themselves in relation to Greek women and other migrant women?

- And finally, what do they hope for their future?

Due to the desire to built an atmosphere of trust between the researcher - a representative of the dominant community - and the women migrants - and especially the 'illegal' ones - the fieldwork was conducted by a combination of methods (cf. Cornelius, 1982). The first step was to get in contact with a key informant whom the migrant women could trust. The key informant brought me in contact with a few Albanian women. These women were very willing to share their experiences and also introduced to me to other women, familiar to them. So, I used the 'snowball' approach for the rest of the interviews. This combination contributed to overcoming the key problem of the 'snowball' method in which the sampling is restricted to the close environment of relatives and friends of the first interviewee.

The interviews with the Albanian women migrant were in-depth and semistructured. This means that each interview had the character of a normal informal conversation. However, some topics/questions were pre-selected by the researcher and appeared in each interview with non-specific order. There were questions that elicited information about the reasons that led to immigration and on the choice of Greece, and Patras specifically, as a destination; questions on the problems that occur during the settlement; questions concerned with the 
problems migrants face in the working environment; questions about their social networks and interactions; and, finally, on their plans for the future.

In the main interview survey eight Albanian women took part, aged 20-55 years old. They are all working women and mothers, and have been living in Greece for up to 10 years. All the interviews were face-to-face, of 1-3 hours duration, and took place in the migrant's home. Some of the interviews were held in the presence of the migrant's relatives (daughters, sons, friends) who took the role of the interpreter when the women did not know or remember a Greek word. The researcher does not speak Albanian and the interviews were held in Greek. During the interviews, notes were taken; the full writing up the interview was done after the end of each interview. The use of a tape recorder was avoided as it was considered damaging for the development of an atmosphere of immediacy and trust between the interviewer and the interviewee (Mishler, 1996). However, I am aware of my limitations as a member of the dominant society, in seeking to understand fully the experiences of these migrant women. In addition to the main interviews, several face-to-face, relatively short informational interviews were held with key informants (landlords, teachers of migrants' children, employers and friends).

The research area is the city of Patras. Patras is the capital of the region of Achaia and the largest in the Peloponnese. After Athens and Thessaloniki, Patras is the third largest city of Greece, with a population of 322,789 inhabitants (Census 2001). It is a major transportation centre, linking Greece with Italy and the Peloponnese with the Ionian islands. This is one of the reasons why it attracts immigrants, as many come to Patras with the hope of crossing to the other side, Italy. Moreover, Patras is a key sea route, via Corfu, that Albanian migrants use in order to get into the country. The city extends from the shore up to the castle. It is divided into two parts, upper and lower. The old part of the city with neo-classical houses is developed around the castle.

\section{THE FIRST DAYS IN PATRAS}

Albania's forty years of isolation from the rest of the world, combined with its disastrous economic, social and political situation, have had a traumatic effect on its citizens (HALl, 1994; VicKers, 1995; Vickers and PetTifer, 1997). In mid-1990 increasing numbers of asylum-seekers started to leave the country longing to start a new life abroad (Vickers and PetTiFER 1997). At the end of 1990, some 3,000 Albanian nationals had arrived in Greece by crossing the border between the two countries without meeting any resistance from Albanian border guards. The great majority were seeking improved economic conditions and work.

These were mainly the reasons that also drove Albanian women to migrate to Greece. The desire to escape from the poor economic situation and the political chaos that has prevailed in Albania and to find a better life somewhere 
else encouraged the migration. Some of the women sold all their property and belongings in order to get the visa and have enough money for their new beginning. Also, as some of the women explained, when the news spread like wildfire that it was possible to leave Albania, it became a psychosis for all to leave and Greece became a common destination. Migration started to seem like the only solution and stories started to spread from the first who had migrated to Greece, so that Greece came to be looked upon as the 'promised land':

In Albania a whole story has been created with those who migrate to Greece. They all believe that those who have left [from Albania] and have come to Greece have now got lots of money and they have gained it very easily. So, a whole story has been created that if you go to Greece you will return back rich. They have no idea how we live here. (Mimoza, 42)

Life in Albania became so hard and difficult. We had neither money, nor jobs. We saw that all were leaving for Greece for a better future and so we decided to do the same. We sold our house, our land, we took our kids and came to Greece. We wanted a better life for them. Not to suffer as we did. (Aggeliki, 50)

The decision to migrate in Greece is generally a family one, at least for the women I interviewed. The couple migrates to Greece in order to find work and a house to live, leaving the children under the care of the grandparents. After a short period - a few months or a year - the migrant woman returns to bring the children with her into Greece. In some circumstances, the grandparents, especially if there is one living alone, follow, too. In the case that there is no grandparent or other relative to look after the children, the migrant woman stays behind with her children and joins her husband after he has settled into the new environment:

We left Albania - me and my husband - to come and work and get some money. We didn't intend to stay long but as soon as we realised that we couldn't earn so easily the money, I returned to bring my kids and my mother with me. It wasn't such an easy task as things had gotten worse in Albania. Under crossfire and out fear of our life, I succeeded to bring my children and my mother to Greece. (Kalliroi, 55)

At first, my husband left and as we had the children, I couldn't go with him. When he found a more stable job, after a year or so, I took the children and came to Patras. (Mamousia, 55)

For the young women of the sample, early marriage and escape to other country with their husband was the only solution to avoid the difficult conditions in Albania:

The situation in Albania is horrible. Especially for us [the women] there is no other way but to get married and leave. I stopped school, married at sixteen and at eighteen, I came to Greece. For me, it was the only way out. (Georgietta, 20) 
The choice of Greece as a destination migration country is based mainly on two reasons: short distance and ease of entry. Most of the women answered that they wanted to be somewhere close to Albania and have the opportunity to return and visit Albania whenever they wanted. One other choice they could have is Italy, but - compared to Greece - the procedure for entry (documents, permit of entry) demands a significant amount of money. For the illegal ones, Greece is relatively close and easy to enter on foot through the mountainous borders:

Most Albanians go to Greece. It is easier and you need less bribe money to pay for the visa. For us it is important that it is near Albania. We could not return and visit if we were far away, for example, in England. Also, my husband left first and so he wanted to be somewhere close so as to return and see us. (Mamousia, 55)

The decision to settle down in Patras was based totally on the work opportunities it offered them and on the social networks Albanians had:

We came straight away to Patras. My husband had his brother here and he helped him to find a job... I also managed to find a job here. (Mimoza, 42)

In some cases, migrant women chose Patras because it was easier to adapt and the cost of living is more affordable. Leaving from small towns and villages, it was easier to find their way around in a city like Patras which is large but not so crowded as Athens:

I didn't want to stay in Athens. I had heard about the noise, the air pollution, the traffic, and in no way did I want to live in such a place. Also, the distance from one place to another is enormous and it would be especially difficult for me since I work in so many different jobs each day. I come from Deropolis and I am not used to such crowded places. (Kalliroi, 55)

The problems that Albanian women faced during their first days in Patras are innumerable. They had to adapt to a new environment, find a house to live in and a job to earn money. With their small savings, they had to spend as little as they could. The situation was even worse for Albanian women who had their children with them. A problem that increased all the difficulties was - and for some still remains - the language. But, even this problem seemed relatively small compared to the hostile environment Albanian migrant women and their families had to face. The racist behaviour of locals made Albanian women feel frustrated and vulnerable:

I don't know what [problem] to mention first. Imagine a family with all its belongings on the streets trying to find somewhere to live. We didn't have much money so we had to restrain ourselves. (Aggeliki, 50)

For me, a big problem was and still is the language. I haven't suceeded to learn it so good and I don't feel so comfortable when I am outside with people. (Marietta, 24) 
At first, we had to face many problems. As you can imagine we were coming from a foreign country, we didn't know the language; it was difficult to find a job and a house. (Kalliroi, 55)

Many problems, many...one thing that even now I cannot accept is the people, their behaviour, it hurts me deeply. In the first days I was sitting alone and I was crying and crying so as to feel better, not to feel so angry and to make this pain stop. (Mimoza, 42)

\section{THE ISSUE OF HOUSING}

One of the first and most vital problems Albanian women migrants have to face when coming to Patras is the issue of housing. The city is divided into two main parts, as noted earlier. Many earthquakes have altered the housing character of the city, which had neo-classical houses and many mansions. Blocks of flats now constitute the main type of housing in the city with a residue of old, neo-classical houses concentrated at the edges of the castle, in the upper part of the city.

Local landlords prefer to rent their apartments to university students who can afford to pay high rents. Migrants, unable to pay such high rents (usually 300 euros per month for a one-bedroom flat) tend to gather in old houses, which the local population has abandoned and does not want to live in anymore. According to the statement of a migrant's landlord:

Usually the locals don't want to rent their houses to families because they are afraid of children damaging the house. Also, they prefer to rent to university students who can afford to pay high rents. Migrants generally have a problem to find a house as the landlords are afraid of renting their house to migrants and especially to Albanians. With all the crimes you hear that they do, I don't blame them. As for me I rent the house to Marietta because I happened to know them before, I have baptised their baby and when I heard that they were looking for a house I agreed to let them stay. I know the house is old and nobody among the locals would have wanted it but if I hadn't known Marietta and her family I wouldn't have rented it to migrants. Maybe that sounds racist but with all that you hear from the newspapers and the TV you get afraid and you must be careful.

Having to face such attitudes, Albanian women really have to struggle in order to find a place to live. During their first days in Patras they live in some third-class hotels in the centre of Patras, which have poor facilities:

The first few days we stayed in an old hotel at Agiou Nicolaou (a central street in Patras) - I don't remember its name - but it is one of the old hotels of Patras. Although we paid a lot of money for the room, it was in really bad condition. (Kalliroi, 55)

The first years of Albanian women migrants in Patras are characterised by residential mobility and instability. They were always on the search for a better, 
more suitable house. At first, some were living out on the periphery of the city and moved to the centre, whilst others changed houses within the centre. Their first houses were really old, in very bad condition, with lots of damp, and lacking basic facilities such as heating or a proper bathroom:

When we first came here we were living in a miserable house. Small, damp, without central heating, we had only a stove. And it was dangerous to live in such a place with all these earthquakes. (Mamousia, 55)

When we first came, the first few months, we lived in a very old house near the castle. It was in a real bad condition, old with moisture, without a bathtub. And I cannot forget how dirty it was. It was really bad in there! (Eva, 29)

After many attempts - each Albanian woman I interviewed had changed at least three houses - they manage to settle into a more decent place. However, it is important to clarify that there is only a slight difference between the houses they live in now compared to the previous ones. Their condition is certainly not equal with that of the locals' houses. They are aware of the fact that with what they can afford to pay they cannot find a better place to live in and to improve their living conditions. Only a few migrants have succeeded in buying their own house, relying on some money they had brought from Albania. These houses are the only ones which are modern and in decent condition:

This house is better than the previous one but it's not perfect. It doesn't have central heating, too. Many times I think of our beautiful house in Albania and I get depressed. I want to move from this house to go to a better one but I know that if I don't find a stable job, I can't afford to change. Where else can we find a place and pay 120 euros? (Mamousia, 55)

In Patras, either you will find good, fine houses or you will find very cheap, old houses. We really found it hard to find a house. At the beginning, we were living in a very old house in Devrenakion Street. Later, we found this place and we decided to buy it with the money we had brought from Albania and the money we should have to give as a rent. I know it's not the perfect house but for sure it's better than the other ones. I like that it has a yard and that it is near the grove. (Aggeliki, 50)

\section{ALBANIAN WOMEN AND THE LABOUR MARKET}

As I have mentioned, the women of my sample had no choice but to migrate in search of better living conditions and work. All women interviewed are working, full-time or part-time. Two are working full-time as domestic workers in Greek households, one is working as live-in domestic worker taking care of an elderly Greek lady, another is working part-time as domestic worker, another two women are working full-time as cleaners in restaurants and another as a full-time employee in a dry cleaner's shop.

It is easily understood why most of the women are occupied as domestic 
workers. Many Greek households employ domestic workers on a full-time or part-time basis. There are many reasons that explain this increase. According to LAZARIDIS (2000), in Greece, until recently, most of the domestic workers employed were working-class Greeks originating from rural areas. Gradually, with an increase in living standards, reduction in internal migration flows from rural areas to urban centres and the acquisition of higher education, Greek women employed in this highly stigmatised sector abandoned this type of work. The gap came to be filled by migrants.

To the above must be added the movement of Greek women into other parts of the labour market. Increasingly more Greek women leave the role of the housewife and caretaker and pursue a working career. Sometimes this happens under the pressure of increasing economic demands in the Greek household. However, this rapid increase of Greek women in waged work is not followed by a change in attitude towards the traditional division of work at home. So, women have to face both responsibilities: at work and at home. To the above difficulty is added another factor: insufficient Greek State provision for childcare facilities. Greek working mothers have a problem of who is going to take care of their child while they are working. So, Greek women, instead of sacrificing themselves, sacrifice their purse and employ migrant women to take care of the house and the children. The observation of ANTHIAS and LAZARIDIS (2000) on the exploitation of migrant women by indigenous women is highly relevant here. The exodus and emancipation of Greek women is followed by the oppression and restriction of mainly migrant women to domestic, traditionally female sectors of the labour market. Migrant women are preferred, as the indigenous population is not so willing to work in such sectors, and in cases that it is willing, it offers its services for high wages.

Migrant women are also employed as domestic nurses for elderly people. According to Kofman et al. (2000), in Southern Europe, welfare services are poorly developed and whereas in the past women in extended families would have been obliged to take care of the elderly, the breakdown of the extended family and the obligations that went with it are leaving a very large gap. In Greece there is an increasing ageing population, but the provisions made by Greece's welfare state do not meet this rise in the proportion of economically inactive elderly persons.

Albanian women in my research have worked in many different places before finding a more stable and secure job. In their first jobs, migrant women were occupied again as domestic workers and cleaners. These jobs were characterised by low wages, insecurity, mobility, exploitation and harassment from the employer:

When I first came to Greece I could find many jobs - something that doesn't happen for the girls migrating now in Greece - but nothing permanent and all employers were trying to find a way to exploit me. So, I worked a couple of days here, a couple of days there. I was paid 1,000 drachmas/per hour (3 euros), which, as you can imagine, is nothing. Of course, I was lucky to get paid because others 
were working and at the end they didn't get anything. My husband had worked for someone, cleared a field and was told that he would get 50,000 drachmas (150 euros) but he didn't get anything. Even now he is trying to get his money back (she laughs ironically). In another job, as a domestic worker again, I was leaving each time totally exhausted but also psychologically depressed. They were yelling at me and generally they were treating me badly like I was their slave. I quit this job, I couldn't stand it. (Mimoza, 42)

I can't remember in how many different jobs I have worked. In the first few days, I got a job only for 15 days to clean a shop. His wife was ill so he needed some help. I got 50,000 drachmas (150 euros); my first salary in Greece. Then, I worked as a waitress in a small restaurant. I worked 2 hours a day and I got 2,000 drachmas per day (6 euros). In the meantime, at the weekends, I worked for another restaurant and I was paid 3,000 drachmas (8 euros) for the whole day. All I can remember is that I worked so hard in all of the jobs. (Kalliroi, 55)

As soon as migrant women get acquainted with the new environment, they began to search for a more secure and profitable job. In their current jobs, most of the migrant women are better paid, feel more satisfied with their salary and their working environment and enjoy more respect from their employers:

Here, in the Student's Union restaurant it is much better. I do not need to take care of elderly ladies who accuse me of stealing from them. I feel much better here. (Clodiana, 25)

Now I work as a domestic worker; it's been eight years since I got this job in this house. I vacuum, I clean, I cook, I do everything in the house. I also have raised their baby who adores me. The lady is so nice to my children and me. She buys them presents, clothes and lots of expensive things. She invites us to her house, we have even dined together. I feel them close to me and I think so do they. But I can understand why they treat me so nice. They had been migrants themselves back in Australia for many years. That's why they can understand and feel for us. (Mimoza, 42)

According to her employer's view, many who have been migrants themselves can understand more their struggle to make a new beginning in a foreign country:

I know Mimoza for 8 years now. I don't think of her only as my employee but as my friend. I can understand completely what they are going through because we have been in the same position ourselves as migrants in Australia. It's really hard to be out of your country.

However it is important to clarify that these migrant women who work full-time, may also work as part-time domestic workers and cleaners in other houses and shops during weekends in order to gain some extra money:

During the week I work as a helper and cleaner in a restaurant. I do everything; I cook, I clean, I vacuum, I take the orders from the customers, I wash the plates. During the weekends I clean this restaurant but also three other shops to get some extra money. My children help me with the weekend's cleaning. (Kalliroi, 55) 
Some women may be satisfied with their salary but not with their working conditions. The situation is especially difficult for the live-in domestic workers:

The hours of my work are too many but this doesn't bother me so. What is really tiring is when the old lady can't remember things and gets irritated and yells. I have to take care of her 24 hours a day... another thing that bothers me, and I don't want is Kleopatra [her daughter] to be raised in such an environment with illnesses and medicines. I know that the grandma adores her but when she loses her mind... and starts to yell, I don't want Kleopatra to be in front of such scenes. (Eva, 29)

All women expressed anxiety as to who will look after their own children when both parents work. One of the reasons for migrant women to work parttime is to take care of their children:

I can't work as I have my baby. Who will look after my one-year-old child? Leaving my child to a childcare unit is the same. I have to work in order to pay the child care facility, so what's the use? When a couple of neighbours, who happen to be his, godparents, can look after him I go and clean a restaurant. (Marietta, 24)

At first, when my children were 5 and 9 years old, I used to lock them in the house and leave them in order to go to work. I didn't have anywhere else to leave them. My mind was always with them, what they were doing, if they were all right. One of my neighbours told me that what I was doing was very dangerous. 'What if a fire breakes out? How they will get out?' she told me. So, from that moment I left the door unlocked and once in a while the neighbour would go and take a look. It was a really bad and stressful situation. (Mimoza, 42)

Albanian migrant women also expressed anxiety as to who will help their children with their studies. Limited time, due to many hours of work, and lack of good knowledge of the Greek language restrict migrant women from dedicating themselves to their children's education:

When I return from work I am exhausted but I don't sit and relax; I have many things to do. The most important is to check my youngest boy to see if he has studied. Compared to the others [her other two children] he is lazy and doesn't sit down to study. I wish I had more time to help him with his homework. (Kalliroi, 55)

One of the teachers of the migrants' children confirmed the anxiety migrant mothers have for the progress of their children:

They come very often and ask about their children; how they progress, what are their weaknesses, but most of all if they behave properly in the school. I can say that many of the migrants' children are very good students and only in the language lessons have problems, which is natural. We know also that they don't have much help from their parents, who work so hard and don't go to any private tuition, as they can't afford it. It is really brave what they have achieved so far, considering the circumstances under which they study. As for us [the teachers], we are trying to help them in every way we can. 
Women migrants who work full-time as domestic workers have generally managed to earn a decent salary, although not equal with that of the indigenous workers. These wages do not increase regularly every year. The majority receives irregular increases in their salary and at the time when the interviews took place no one knew how much it would be increased by the next year. Usually it depends on the will of the employer and whether he/she is convinced that the migrant woman works well and, what is more, can trust her. Most of the women are given one day-off, usually Sunday.

All migrant interviewees stated that they are working without social security benefits. They do not get paid for working extra hours or on bank holidays. Although they acknowledge the importance of having insurance, they confess that Greek employers do not employ migrants who ask for insurance benefits. So, migrant women prefer to ask for higher salary and work without insurance. Some consider paying their insurance contributions by themselves:

I know that I don't get social security benefits but what can I do? Nowhere can you find a job and get insurance at the same time. I thought of private insurance but when I got informed about it [from one private insurance company] it seemed to me as a theft. To give so much money and at the end to keep half of it? I better leave it! I thought it better to put the money in a bank and to use it whenever I needed. (Kalliroi, 55)

I like this job because I am insured. Of course, don't imagine that they put all of my stamps [for the insurance] but the girls that I know don't have insurance at all. I have to pay for the rest from my own salary because if I want to stay in Greece and be legal, I have to have paid 150 stamps. (Georgietta, 20)

None of the Albanian interviewees have had any serious accident while working. Only small injuries and minor breathing problems:

Until now, I haven't had any serious accident, only some small injuries. For example, one day while I was cleaning the restaurant, I mixed many detergents together into the bucket and from the fumes I couldn't breathe and I started to cry. But I washed my hands, my face, I got outside to take some fresh air and then everything was fine. (Kalliroi, 55)

However, many migrant women told stories of their visits to the local hospitals due to the illness of their children. Being uninsured, they are vulner-able in such situations and have to depend on their husband's insurance:

We took Kleopatra to Karamandanion [local public hospital only for children] because she had a serious infection under her arms. The doctors treated us really nice, but I am really glad that my husband has insurance because we couldn't afford to pay for the medicines. (Eva, 29)

Of course, if something serious happens to us or to our children, we are lucky because we have my husband's insurance. (Kalliroi, 55) 
For the migrant women of my research, it was not the first time to work. Most had been working back in Albania but with the economic changes they lost their job. All are educated; three have finished basic primary education, two secondary and three have a university degree. All of them have accepted unskilled work, and for some this is well below the level of their qualifications. From a dressmaker who works as a cleaner in a restaurant to a chemist who works as a live-in domestic worker, all women experience what some have called 'brain waste' (Kofman et al. 2000). To the above deskilling of migrant women contributes also the lack of good knowledge of the Greek language. Furthermore, their university degrees are not automatically valid in Greece, only after a procedure of extra examinations. Yet Albanian women cannot participate in such examinations due to the language problem they face:

Back in Albania, I was an accountant and a good one but here I can't do the same job. I don't know the language and the accounting legislation. (Kalliroi, 55)

I can't find work as a chemist as my university degree isn't recognised here. (Eva, 29)

Albanian migrant women are often perceived to pose a treat to the employment of local women and especially to domestic workers. But, as we have seen, migrant women tend to work in sectors where local working-class women themselves refuse to work. They come to fill shortages in jobs where no one else really wants to work. As for the fears of contributing to inflation, this too does not happen. If anything, exactly the opposite happens.

\section{SOCIAL NETWORKS OF ALBANIAN MIGRANT WOMEN}

The neighbourhood is the first place where Albanian migrants meet the locals. The relations that develop are fairly typical. We could summarise the whole relationship in one phrase: 'as long as you do not bother me, we are good neighbours'. However, some would argue that the typical old neighbourhoods where children could play on the street, where women would sit and talk outside their doors, where one knew one's neighbours very well, have been lost a long time ago. Yet in the areas where migrants live - mostly near the castle - the above picture is still preserved to some extent and one can still see the housewives gossiping and children playing on the streets. In these neighbourhoods, Albanian migrant women can actually feel more isolated and undesirable, more as 'foreigners':

I don't know why they treat us like this. I am going to tell you about an incident that happened to me. I had gone to the bakers' shop. They gave me bread that I hadn't asked for and I didn't want. I asked for another one. Do you know what the woman said to me: 'Look who wants another loaf, the Albanian who until yesterday didn't know what bread was'. I just asked for another loaf, that's all. I felt really bad. Why did she tell me that? (Marietta, 24) 
Furthermore, even in the areas where neighbourhood relations are normal and restricted to usual daily greetings, the attitude differs towards Albanian women:

When we first came to this house all the neighbours were really friendly. They understood that we were foreigners but they didn't know that we were Albanians. As soon as they learned it, they stopped greeting us. (Georgietta, 20)

Of course, there are exceptions where locals seem to understand and act more acceptably, by helping immigrants in difficult situations:

There are many people that have treated me badly but there are also people who have helped me in really difficult situations. I will never forget one of my neighbours how she stood by my side and helped me when my girl was ill and had to get to the hospital. She drove us to the hospital, she talked to the doctors, she did the papers in the hospital, and she even gave me money. I know that she is a nurse and from her profession has learned to help people but it wasn't the first time that she helped me. For me, she is just human. (Clodiana, 25)

When I met her friend, she told me: 'I cannot understand why other people treat them (Albanians) worse than animals. I think they get afraid from what they watch on the television. They have been through a lot; I don't know why they make them suffer more'.

The main relationships that Albanian women create are with other women of the same nationality. Many of the interviewees knew each other and were friends, although I acknowledge that this was partly a function of the snowball sampling method. Although their heavy, daily schedule does not allow them much time to meet, they try to find spare time in order to drink a coffee, talk and share their problems. It is also a common entertainment for the families to meet - usually on Sundays - in each other's houses and have a meal together. It does not occur to them to meet and mix with women migrants of different ethnicities or nationalities, except some who keep contact with ethnic-Greek Albanians who come from the same place back in Albania:

In Patras we've got only friends and, whenever we can, we meet and talk. (Mimoza, 42)

I have got my friends, mainly Albanians but also ethnic-Greek Albanians, as you call them, and we can talk. (Kalliroi, 55)

Regular contacts are kept with family and relatives back in Albania. Through letters and the telephone, they exchange news and some share their problems:

I've got my family back in Albania. We have regular contact. During the first years, when I had so many problems, I used to tell them, I couldn't keep them inside me. (Mimoza, 42)

Others, however, conceal their problems from their family because they do not want to make them feel sad or to damage the image of the successful life migrants appear to have in Greece: 
I keep regular contact with my family. I send them letters, I call them on the phone and Kleopatra [her daughter] sends them her paintings. I don't want to worry them with my problems. I want to make them feel that I am all right. (Eva, 29)

News from their country can also be learnt from the Greek television and radio, which are the main sources of their entertainment. These include occasional Albanian-language broadcasts. In their limited spare time they prefer to watch television or go for a walk with their families in the city centre:

We don't go out often. Our only entertainment is the TV. We watch movies, the news and the news about Albania... Sometimes we go out to the shops with my kids but when you see all those things that you can't afford to buy, you get depressed. (Mamousia, 55)

Although most interviewees declared themselves to be atheists, there were a few who said that through their religious activities they had created some of their friendships. Amongst my interviewees were women from each of three religions of Albania - Orthodox, Catholic and Muslim (although religion had been banned by the Albanian Communists). Especially for the Orthodox Christians, to express freely, without fear, their religious feelings was seen as a delightful experience. Also, for the Albanian Catholics, it is important to feel that there is a church and a large Catholic community they can turn to. Unfortunately, it does not happen in the same way with the Muslims who have to change their names into 'Christian' ones in order to be more acceptable to the Greek community. Due to historical events, being Muslim is related in common logic with Turks and with the 400 years of Ottoman domination and the recent political conflicts between the two countries:

Here in Greece we know that you don't like Muslim people due to historical reasons and all you've been through from the Turks. But we are not Turks, just Muslims. If you tell someone that you are Albanian, they don't like you so much, but if you are Albanian and Muslim, then they are capable of hating you forever. We say our prayers secretly, we don't admit that we are Muslims, it's like in Albania, the same old situation. (Mamousia, 55)

All the Albanian women who took part in the interviews had baptised their children as Orthodox Christians or intended to do so, in order that their children will not experience any kind of discrimination:

We are Catholics but Kleopatra is baptised Orthodox. We didn't want her to be different from the other children. (Eva, 29)

My husband and I are Catholics. We go to the Catholic Church here in Patras. Here, there is a large Catholic community. However, our child is baptised Orthodox. We don't believe that we have many differences from the Orthodox. We didn't want our chlid to be different from the other kids or to face any problems due to the religion. (Marietta, 24) 


\section{MAKING PLANS FOR THE FUTURE}

Albanian women migrated to Greece with the dream of a better life. Many of them had initially taken the decision to migrate and stay for a few months in order to gain some money and return to Albania with a sufficient amount of money to improve their living conditions. Soon they realised that it was not possible to earn money easily and started to make more realistic future plans:

At first, I was planning to stay for six months and then to return. How could I imagine that I would stay for so long; it's been eight years now. I could never have imagined it! If someone back then would have told me such a thing, I would laugh (Kalliroi, 55)

On the other side, there are some women who could not afford to come to Greece unless they sold their belongings. It became easily apparent to them that they would stay for a long time in Greece and there was no possibility of returning back:

We sold our house, our field... we don't have anywhere to return to or anyone to wait for us. (Aggeliki, 50)

Many of the women had made various plans and had many hopes when coming to Greece. Many have been disappointed, but still hope for a better future for themselves and their families:

At first, I came with many dreams; that I would get a good job with lots of money so as to have all the things that I have missed all these years. However, I soon realised that things weren't so easy. But I still hope; little by little things change for the better. (Mimoza, 42)

On the other hand, others have stopped making plans and dreams so as not to get disappointed, while other women avoid thinking of their future, as they feel insecure about prolonging their stay in Greece:

I didn't expect things to be like that. I had imagined them much better. I thought that life here would be really good; I was wrong. Things are so difficult, so difficult. (Aggeliki, 50)

I had many expectations, I didn't expect this situation. Of course, I knew that it would be difficult but nothing like that. I don't know, I am very pessimistic about our future. (Eva, 29)

Plans? How can you make plans for the future? I don't even know if they will renew my stay here in Greece. (Georgietta, 20)

None of the women had expected to find such a hostile attitude towards them:

I didn't expect that people would treat us in such a way. I thought that they would understand how much we have suffered. (Mamousia, 55) 
I don't know why they treat us like this. Very weird people! I think that they are afraid of us. (Marietta, 24)

Despite all the difficulties and disappointments, migrant women confessed that there is no way back. They acknowledge the fact that the ruined economy of Albania will need many years in order to be restored. They foresee their future in Greece, as they have already invested so much effort and money to start a new beginning. Only a few hope to return with their husbands in the indefinite future to their country, leaving their children in Greece:

There is no return to Albania. We decided to come here and have a new life. We don't intend to go back, there is nothing for us back there... in Albania, things will never change. The situation is too bad and it will only be after many years that things there will change. Of course, if they expel us from here, we will have nowhere else to go. (Georgietta, 20)

I don't think that I will ever return back. I want to, but I don't think so. My children have become adjusted to this way of life and here [in Greece] they are going to build their future. Only my husband and I might return some day. My kids don't even want to go for holidays in Albania... Here in Greece we will try to build our future. (Kalliroi, 55)

Younger migrant women think of the possibility to migrate to another country, with the main destinations being Italy and United Kingdom, where circumstances seem to them better:

We are thinking of staying here [in Greece]. Of course, if we could find money, we would like to go to England. There, it is better than anywhere else. They welcome you and they find you a house and job. There, they aren't racists, too. (Marietta, 24)

It would be nice if we could go to Italy but you have got to have a lot of money to pay for the papers. There, you can find easily jobs with lots of money and they don't care if you are black, white, Albanian or Italian, just to do your job as best as you can. (Georgietta, 20)

Women's hopes for the future focus on their children's education and a better life. Living in Greece is seen as a sacrifice for the sake of the children:

Back in Albania, we've got a very good house but we don't have jobs and money. Also, it is very dangerous if you've got a child; it's not safe. Do you know how many kids they abduct every day in order to remove their liver or to sell them or to involve them in prostitution? I want to stay in Greece for the future of my child. I want my child to be safe and be educated and build a life here. There is no future for a child back in Albania. (Eva, 29)

We came here to stay and fight for a better future for our children. Only for them I hope and pray and struggle for a better future. (Aggeliki, 50)

It is somewhat surprising that migrant women want their children to have a good education where they can learn to speak many languages, among them Greek but not Albanian. They argued that they want to teach their children 
about the Albanian language and history. Although they did not clarify the reasons for not wanting a multi-cultural education, it seemed to me that they do not trust the Greek educational system on such matters:

I want my children to be well educated, to learn to speak many languages. However, I want to teach them Albanian myself. They don't need to learn it at school (to me, if she wants special classes in which Albanian language and culture can be taught to children after school). No, I don't want something like this for my children. I want them to learn these things from their own family. (Clodiana, 25)

Other women expressed anxiety and disapproval in case their children fall in love with, or even marry, Greek women or men. They are afraid that their children will not be treated as equals in such a relationship:

I want my children to be healthy, to be educated and to succeed in their lives. What I don't want to happen in their lives is to fall in love with or even want to marry a Greek girl... because they will never see them as equals, they will always be considered as Albanians. Maybe the girl is in love and respects him but not her parents and relatives, they will never accept him. No, I will never want something like this to happen. (Mimoza, 42)

Sometimes I think what will happen if they get married to a Greek person but then I calm down as I am thinking that no Greek person will choose to marry an Albanian. (Mamousia, 55)

As regards their plans for their working conditions, migrant women who have part-time employment want and try to find a permanent job:

I would like to find a permanent job so as to contribute more to the expenses of the household and to be able to save some money. But most of all, I want to work so as not to be alone in the house for so many hours when my husband and my kids are out. (Mamousia, 55)

It is interesting to point out that none of the women includes in her future plans the possibility of creating her own business. The response to the question about whether they think to set up their own business in the future is disarming:

And who will want to buy anything from an Albanian's shop? (Marietta, 20)

Furthermore, none of the young migrant women intends to have another child:

We don't even think of having another baby. It is difficult enough now that we have only one child. (Marietta, 20)

No, for the present and under such circumstances I don't want another child. I know that it is hard for a child to grow up alone without a brother or sister. If things change for the better I would want another child, especially as company for Kleopatra [her daughter]. (Eva, 29) 
One common wish among Albanian migrant women is for a change in the attitude of the inhabitants of Patras towards them:

I've got one grievance. I wish the inhabitants of Patras stopped making us feel unwanted. Before even they get to know us, they don't want to have any relation with us. I don't understand. Why? (Aggeliki, 50)

\section{CONCLUSIONS}

'As a woman I have no country.

As a woman I want no country. As a woman, my country is the whole world'

(V. WoOLF, 1938)

Virginia Woolf's famous statement is attractive in implying a disloyalty to patriarchal civilisation, a disregard of narrow nationalist definitions, and a sisterhood across ethnic boundaries. However, this dictum does not apply in our case. Albanian migrant women do not have the opportunity to choose to have no country and all that this means, but are driven to migration by economic necessity and also by the political instability that prevails in Albania. Hoping to find better conditions, they migrate to their neighbouring country, Greece, which appears as the 'promised land'. However, soon they realise that Greece is still trying to cope with its transformation from an emigration to immigration country. Changes in immigration policies follow one another, without properly informing immigrants; illegals are being prosecuted and the media portrays them as the source of all evils. In such a challenging environment women try to build their lives, as they know that there cannot be a return back to their country. They feel that they stay in Greece for the safety and future of their children. Their role is dual: working women and caring mothers. Women are a source of family support and strategy not only for the members living with them but also for those who have been left behind in Albania.

Some women in my small sample were among the first to migrate to Patras, so they did not have any support networks of relatives or friends. Only with the support of their husband, they tried to settle down in the new environment. Most of the migrant women are employed as domestic workers. The increasing full-time employment of local women and the poor welfare provisions and state facilities for childcare and for the elderly have increased the demand for domestic workers. This labour structure leads to a division among women and particularly between local women and migrant women where the first contribute to the employment but only by their confinment of the latter to traditional, stigmatised domestic sectors.

Many of the accounts of migrants' work are very grim from both a physical and a mental viewpoint: long hours of arduous work often involving emotionally 
demanding work with children and the elderly. They are working under such conditions without any insurance or other social security benefits. Most of the women are educated but accept unskilled work well below the level of their qualifications. But it would be wrong to paint a picture of migrant workers only as victims. It is vital to also look at the migratory experience as a process of potential empowerment. Most women are able to send remittances back to Albania and improve their situation here, some even buying a house.

The type of accommodation migrant women live in is generally degraded. Usually Albanian women rent old houses or squalid flats with their family, depending on where they can find something with a low rent. Their flats and houses are scattered all over the city with a concentration around the Castle area where many of the old houses are located. However, there is no formation of ethnic 'ghettos' or neighbourhoods in Patras. The interiors of the majority of the Albanian houses are very old, simply furnished, poorly decorated and with a lot of damp.

One of the dreams of Albanian women is to improve their economic situation so that they can live in a better house or even buy one. Only two of the women have succeeded in this. Another hope is to change the hostile behaviour of the local people towards them, so as to be able to live peacefully with their families in Patras.

This research has tried to approach the living and working conditions of Albanian migrant women in Patras. Its contribution lies in the fact that it has used mainly qualitative material relating to an under-explored area - gender and migration in Greece - and that it brings to the forefront the migrant women themselves. However, what is certain is that one piece of research - and especially so small in its sample - on this subject is not enough. Further studies on matters concerning migrant women in Greece need to be done.

\section{ACKNOWLEDGEMENTS}

This article is based on my MA dissertation completed in the Department of Geography, University of Leeds in 2001. I would like to thank Dr. Deborah Phillips for her help throughout the process of the research. I would also like to thank Professor Russell King for his help and encouragement during the writing of this article.

\section{REFERENCES}

ANTHIAS, F. and LAZARIDIS, G. (eds.) (2000)-Gender and Migration in Southern Europe: Women on the Move. Oxford: Berg.

Anthias, F. (1992)-Ethnicity, Class, Gender and Migration: Greek-Cypriots in Britain. Aldershot: Avebury. 
CAMPANI, G. (2000) - Immigrant women in Southern Europe: social exclusion, domestic work and prostitution in Italy. In KING, R., LAZARIDIS, G. and Tsardanidis, C. (eds.)-Eldorado or Fortress? Migration in Southern Europe. London: Macmillan.

- (1999) - Trafficking for sexual exploitation and the sex business in the new context of international migration: the case of Italy. In BALDWIN-EdWARDS, M. and ARANGO, J. (eds.) - Immigrants and the Informal Economy in Southern Europe. London: Frank Cass.

Castles, S. and Miller, M. (1998) - The Age of Migration: International Population Movements in the Modern World, $2^{\text {nd }}$ ed., London: Macmillan.

CHell, V. (1997) - Gender-selective migration: Somalian and Filipina women in Rome. In KING, R. and BLACK, R. (eds.) - Southern Europe and the New Immigrations. Brighton: Sussex Academic Press.

CORNELIUS, W. - Interviewing undocumented immigrants: methodological reflections based on field work in Mexico and U.S. International Migration Review, 16(2): 378-411.

Essed, P. (1995) - Gender, migration and cross-ethnic coalition building. In LuTz, H.; Phoenix, A. and Yuval-Davis, N. -Crossfires: Nationalism, Racism and Gender in Europe. London: Pluto.

FAKIOLAS, R. (2000) - Migration and unregistered labour in the Greek economy. In KING, R.; LazARIDIs, G. and Tsardanidis, C. (eds.)-Eldorado or Fortress? Migration in Southern Europe. London: Macmillan.

FAKIOLAS, R. and KING, R. (1996) - Emigration, return immigration: a review and evaluation of Greece's post-war experience of international migration. International Journal of Population Geography, 2(2): 171-90.

GlYTsos, N. (1995) - Problems and policies regarding the socio-economic integration of returnees and foreign workers in Greece. International Migration, 23(2).

HaLl, D. (1994) - Albania and the Albanians. London: Pinter Publishers.

IosIFIDES, T. (1997)-Immigrants in the Athens labour market: A comparative survey of Albanians, Egyptians and Filipinos. In KING, R. and Black, R. (eds.)-Southern Europe and the New Immigrations. Brighton: Sussex Academic Press.

KARYDIS, B. (1996) - Criminality of Immigrants in Greece: Questions of Theory and Non-criminal Policy. Athens: Papazisi Publications (in Greek).

KATSORIDAS, D. (1994) - Foreign Workers in Greece.Athens: IAMOS (in Greek).

Kofman, E.; Phizacklea, A.; Raghuram, P. and Sales, R. (2000) - Gender and International Migration in Europe: Employment, Welfare and Politics. London: Routledge.

Kofman, E. and Sales, R. (1992) - Towards Fortress Europe? Women's Studies International Forum, 15(1): 29-39.

LAZARIDIs, G. (2000) - Filipino and Albanian women migrant workers in Greece: multiple layers of oppression. In ANTHIAS, F. and LAZARIDIS, G. (eds.) - Gender and Migration in Southern Europe: Women on the Move. Oxford: Berg.

- (1999) - The Helots of the New Millennium: Ethnic-Greek Albanians and 'Other' Albanians in Greece. In ANTHIAS, Fl. and LAZARIDIs, G. (eds.) - Into the Margins: Migration and Exclusion in Southern Europe. Aldershot: Ashgate.

MishleR, E. (1996)-Research Interviewing. London: Harvard University Press.

Morokvasic, M. (1991) - Fortress Europe and Migrant Women. Feminist Review, 39: 69-84.

_ (1984) - Birds of passage are also women. International Migration Review, 18(4): 886-907.

- (1983) - Women in migration: beyond the reductionist outlook. In PhizackleA, A. (ed.) - One Way Ticket: Migration and Female Labour. London: Routledge \& Kegan Paul. 
Mousourou, L. (1991) - Immigration and Migrational Policy in Greece and in Europe. Athens: Gutenberg (in Greek).

Petrinioti, Xs. (1993) - Migration to Greece: A primary mapping, classification and analysis. Athens: Odysseus \& Bibliothiki Institute Diethnon Sxeseon (in Greek).

Phizacklea, A. and Wolkowitz, C. (1995) - Homeworking Women: Gender, Racism and Class at Work. London: Sage.

Phizacklea, A. (ed.) (1983) - One Way Ticket: Migration and Female Labour. London: Routledge \& Kegan Paul.

Phizacklea, A. and Miles, R. (1980) - Labour and Racism. London: Routledge \& Kegan Paul.

Psimmenos, I. (1995)-Immigration from the Balkans: Social Exclusion in Athens. Athens: Papazisi Publications (in Greek).

Pteroudis, E. (1996) - Emigrations et immigrations en Grèce: evolutions recentes et questions politiques. Revue Européenne des Migrations Internationales, 12(1): 159-189.

RomaniszYN, K. (1999) - The presence of polish undocumented in Greece in the perspective of European unification. In ANTHIAS, Fl. and LazARIDIs, G. (eds.)-Into the margins: Migration and Exclusion in Southern Europe. Aldershot: Ashgate.

Simon, G. (1987)-Migration in Southern Europe: an overview. The Future of Migration. Paris: OECD: 258-91.

Simon, J. and Brettell, C. (eds.) (1986)-International Migration: The Female Experience. New Jersey: Rowman and Allenheld.

Vickers, M. and Pettifer, J. (1997) - Albania from Anarchy to a Balkan Identity. London: Hurst.

VICKERS, M. (1995 - The Albanians, a Modern History. London: I.B. Tauris.

WING (Women, Immigration and Nationality Group) (1985) - Worlds Apart: Women under Immigration and Nationality Law. London: Pluto Press.

Woolf, V. (1938) - Three Guineas. London: Penguin. 